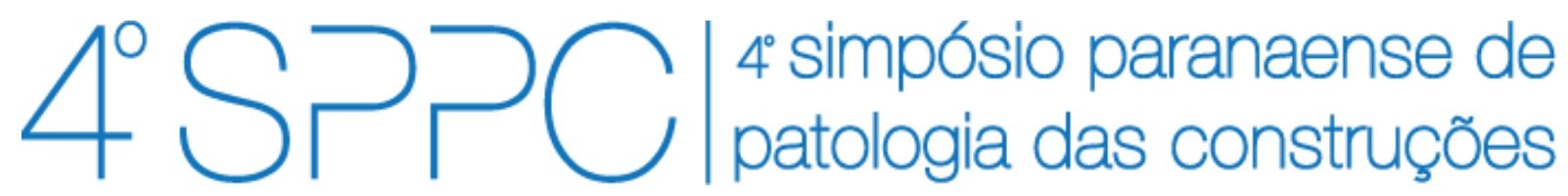

ISSN 2526-7248 artigo n. 4SPPC159, pp. 534-546, 2019

\title{
Application of the kinetic analysis in the accelerated test of alkali- silica reaction in aggregates for concrete
}

\author{
Vila, Patricia Elizabet ${ }^{1}$; Pereyra, María Noel ${ }^{2}$ \\ ${ }^{1}$ MSc., Facultad de Ingeniería, Universidad de la República, pvila@fing.edu.uy \\ 2 Dr., Facultad de Ingeniería, Universidad de la República, mpereyra@fing.edu.uy
}

\begin{abstract}
The kinetic analysis of the expansion according to RILEM AAR-2 in the accelerated mortar bar test (AMBT) is presented up to 14 days of immersion in the aggressive solution $\mathrm{NaOH}$ for the evaluation of the alkali-silica reaction potential of the aggregates for concrete.

The kinetic parameters Lnk and $M$ were good indicators of the magnitude and evolution of the expansion with the test age. Therefore, the interpretation of the test AMBT is improved with the use of both parameters.

The model allows the expansion estimation at ages older than 14 days, in this case at 21 and 28 days of immersion. However, the error in the estimation should be considered.
\end{abstract}

Keywords: Alkali-Silica Reaction. Accelerated Mortar Bar Test. Kinetic Analysis. 
VILA, P; PEREYRA, M.N. APPLICATION OF THE KINETIC ANALYSIS IN THE ACCELERATED TEST OF ALKALI-SILICA REACTION IN AGGREGATES FOR CONCRETE. $4^{\circ}$ Simpósio Paranaense de Patologia das Construções (40 SPPC), artigo 4SPPC159, pp. 534 - 546, 2019. DOI: 10.4322/2526-7248.075

\section{Introduction}

The alkali-silica reaction (RAS) is an internal reaction in concrete that occurs between certain minerals of aggregates (opal, chalcedony, quartz, tridymite, cristobalite, chert and volcanic glass) considered "reactive" and the alkalis (sodium and potassium ions) provided mainly from Portland cement. An alkaline medium is necessary for the reaction to be developed, which is commonly found in the solution in concrete porosity. A consequence of this and in presence of moisture, the reaction products expand, causing cracking and reducing significantly the service life of the affected structure. In addition, the reaction products can cause leaching stains on concrete surface [1].

For this reason, great efforts have been made to develop test methods to evaluate the aggregate reactivity and the deleterious degree of the reaction. Nowadays there are several internationally recognized standardized tests, such as the accelerated mortar bar test [2] [3] [4] [5], the semi-accelerated concrete prism test [6] [1] and long-term concrete prism test (with a duration of one year or more) [7] [6]. The criteria to define the reactivity of the aggregate arises from the expansion obtained after the mortar or concrete bars have been submitted in an aggressive environment for a predetermined period of time.

Although the accelerated mortar bar test (AMBT) has the advantage that the results are obtained in a short term (16 days after the bars are fabricated), it has some limitations. On one hand, an aggregate which was considered reactive in the accelerated test, it could not be reactive in service. On the other hand, in the case of certain types of aggregates that are considered of "slow reaction", the interpretation of the expansion test - after 14 days of immersion in the aggressive solution - has been questioned. From the existing tests, the long-term concrete prism test is the one that best represents the behaviour of the aggregate in service [8]. However, due to the time that takes the accelerated mortar bar test, it is still largely used for characterizing aggregates in terms of their potential reactivity.

Recently, the RILEM Technical Committee 219-ACS worked on the development of different laboratory test methods for the evaluation of RAS and on the specifications to minimize the damage caused in hydraulic concrete structures. The recommendations included a new method for the interpretation of the result of the AMBT based on the kinetic analysis of the expansion evolution within the test time [1]. Johnston y Fournier [9] were the first to introduce this interpretation method, applying the mathematical model known as Kolmogorov-Avrami-Mehl-Johnson (abbreviated Model KAMJ).

The expansion presents a sigmoid behaviour function called "s-shaped curve" that depends on the test moment. At the beginning there is a significant increase of the expansion in a short time, but after passing through an inflexion point, it decreases progressively towards an asymptotic value [10]. The mathematical model of KAMJ describes the nucleation and the reaction growth kinetics and the transformation phase in the asymptotic stage of the reaction. In this model the percentage of expansion $E_{t}$ is exponentially related with time $t$ (in days) as shown in the Eq.1:

$\operatorname{Et}(\%)=1+E_{t 1}(\%)-e^{-k(t-t 1)^{M}}$ 
VILA, P; PEREYRA, M.N. APPLICATION OF THE KINETIC ANALYSIS IN THE ACCELERATED TEST OF ALKALI-SILICA REACTION IN AGGREGATES FOR CONCRETE. $4^{\circ}$ Simpósio Paranaense de Patologia das Construções (40 SPPC), artigo 4SPPC159, pp. 534 - 546, 2019. DOI: 10.4322/2526-7248.075

Where $E_{t 1}$ is the degree of reaction in time $t_{1}$ (in days) when the nucleation and growth become dominant and $k$ a constant associated with the reaction rate that combines the effects of nucleation, multidimensional growth, reaction products geometry and diffusion. $M$ is an exponential term related with the growth and shape of the nucleation. This model can be applied to the development of the expansion both in mortar bars and in concrete prisms [9] [10] [11].

From the expansion results up to 14 days of immersion in the AMBT and considering the kinetic criterion for the interpretation of the results indicated by the RILEM recommendation, the Lnk and $M$ coefficients were calculated for 21 aggregate samples. These coefficients allow to define the criteria of reactivity in future works.

For the aggregates presenting an intermediate expansion after 14 days of immersion in the AMBT, the test standard indicates to continue up to 28 days. The aim of the work was to evaluate the accuracy of the model to predict the expansion at 21 and 28 days adopting the coefficients of the kinetic model calculated up to 14 days of immersion. To do this, the prediction results of the model were compared with the experimental data of expansion obtained at both ages. The error of the estimation was calculated.

\section{Materials and Methodology}

\subsection{Materials}

A Normal Portland Cement - identified as CPN by the standard UNIT 20 [13] - was used to produce the mortars. This cement is for general use in concrete and contains only clinker as the main component, without additions. The samples used have an equivalent alkali content $\left(\mathrm{Na}_{2} \mathrm{O}_{\text {eq }}\right)$ between $1.16 \%$ to $1.29 \%$, an average autoclave expansion of $0.11 \%$ and a specific surface (Blaine) of $330 \mathrm{~m}^{2} / \mathrm{kg}$.

Different types of aggregates were used on this study, all of them considered suitable for concrete according to standard UNIT 1050 [12]. A total of 21 samples were tested: 13 coarse aggregates and 8 fine aggregates. Table 1 shows the identification of each sample, origin, summary description, and reactivity according the AMBT test [3].

Except the samples $\mathrm{N}^{\circ} 8, \mathrm{~N}^{\circ} 9$ and $\mathrm{N}^{\circ} 10$, the coarse aggregate considered were crushed stone - material that proceeds from a crushing process carried out in the extraction place to obtain a particle size suitable for concrete - and all sands were from natural origins except samples $\mathrm{N}^{\circ} 14$ and $\mathrm{N}^{\circ} 15$.

The criterion for defining "coarse sand" and "fine sand" arises from its particle distribution. Coarse sands present large particle size, in Uruguay generally the highest proportion in these is retained in the sieves of greater aperture (between $2.36 \mathrm{~mm}$ and $0.30 \mathrm{~mm}$ ). The fine sands usually present particle size between $0.30 \mathrm{~mm}$ and $0.15 \mathrm{~mm}$. Both types of fine aggregates must be mixed to form a particle distribution suitable to be used in concrete. 
Table 1: Characteristics of the aggregates used for the analysis.

\begin{tabular}{|c|c|c|c|c|c|}
\hline$\underset{\mathbf{N}^{\circ}}{\text { Sample }}$ & $\begin{array}{l}\text { Sample } \\
\text { Id. }\end{array}$ & $\begin{array}{l}\text { Type of } \\
\text { aggregate }\end{array}$ & Origin & $\begin{array}{l}\text { Summary } \\
\text { description }\end{array}$ & $\begin{array}{l}\text { Expansion } \\
\text { at } 14 \text { days } \\
\text { (IRAM 1674) }\end{array}$ \\
\hline 1 & 2PPM 2 & Coarse & \multirow{2}{*}{ Minas, Laballeja } & \multirow{2}{*}{$\begin{array}{c}\text { Crushed stone. } \\
\text { Quartzite }\end{array}$} & 0.4252 \\
\hline 2 & 2PPM 1 & aggregate & & & 0.3581 \\
\hline 3 & 2PPD 3 & $\begin{array}{c}\text { Coarse } \\
\text { aggregate }\end{array}$ & $\begin{array}{l}\text { Ruta } 5 \mathrm{Km} 480, \\
\text { Tacuarembó }\end{array}$ & $\begin{array}{l}\text { Crushed stone. } \\
\text { Volcanic rocks }\end{array}$ & 0.2992 \\
\hline 4 & MCHA 1 & $\begin{array}{c}\text { Coarse } \\
\text { aggregate }\end{array}$ & \multirow{4}{*}{$\begin{array}{c}\text { Minas de Corrales, } \\
\text { Rivera. }\end{array}$} & \multirow{4}{*}{$\begin{array}{l}\text { Crushed stone. } \\
\text { Gabbro rock }\end{array}$} & 0.2748 \\
\hline 5 & MCHA 2 & $\begin{array}{c}\text { Coarse } \\
\text { aggregate }\end{array}$ & & & 0.3079 \\
\hline 6 & NHA 1 & $\begin{array}{c}\text { Coarse } \\
\text { aggregate }\end{array}$ & & & 0.0629 \\
\hline 7 & NHA 3 & $\begin{array}{c}\text { Coarse } \\
\text { aggregate }\end{array}$ & & & 0.0901 \\
\hline 8 & 1PR48 1 & \multirow{3}{*}{$\begin{array}{l}\text { Coarse } \\
\text { aggregate }\end{array}$} & \multirow{3}{*}{ Melilla, Canelones } & \multirow{3}{*}{$\begin{array}{l}\text { Natural stone. } \\
\text { Granite rock }\end{array}$} & 0.0239 \\
\hline 9 & 1PR48 2 & & & & 0.0269 \\
\hline 10 & 2PR48 1 & & & & 0.0292 \\
\hline 11 & 1PPCP 1 & $\begin{array}{c}\text { Coarse } \\
\text { aggregate }\end{array}$ & $\begin{array}{c}\text { Cerro Méndez, Treinta y } \\
\text { Tres }\end{array}$ & $\begin{array}{l}\text { Crushed stone. } \\
\text { Limestone rock }\end{array}$ & 0.0169 \\
\hline 12 & CMG 1 & Coarse & \multirow{4}{*}{ Carrasco, Montevideo. } & \multirow{4}{*}{$\begin{array}{l}\text { Crushed stone. } \\
\text { Granite rock }\end{array}$} & 0.0852 \\
\hline 13 & CMG 2 & aggregate & & & 0.0757 \\
\hline 14 & CMF 1 & \multirow{2}{*}{ Fine aggregate. } & & & 0.0743 \\
\hline 15 & CMF 2 & & & & 0.1004 \\
\hline 16 & 2AGC 1 & \multirow{4}{*}{$\begin{array}{l}\text { Fine aggregate } \\
\text { (Coarse sand) }\end{array}$} & \multirow{2}{*}{$\begin{array}{l}\text { Aguas Corrientes, } \\
\text { Canelones. }\end{array}$} & \multirow{2}{*}{$\begin{array}{l}\text { Natural sand. } \\
\text { Quartz- } \\
\text { Feldspatic sand }\end{array}$} & 0.1335 \\
\hline 17 & $2 A G C 2$ & & & & 0.1228 \\
\hline 18 & 1AGPP 1 & & Paso Pache, & Natural sand. & 0.1489 \\
\hline 19 & 1AGPP 2 & & Canelones. & Quartz sand. & 0.1453 \\
\hline 20 & 3AFT 1 & \multirow{2}{*}{$\begin{array}{l}\text { Fine aggregate } \\
\text { (Fine sand) }\end{array}$} & \multirow{2}{*}{$\begin{array}{c}\text { Delta del Tigre, San } \\
\text { José }\end{array}$} & \multirow{2}{*}{$\begin{array}{c}\text { Natural sand. } \\
\text { Quartz- } \\
\text { Feldspatic sand. }\end{array}$} & 0.0677 \\
\hline 21 & AFT 1 & & & & 0.0639 \\
\hline
\end{tabular}

For the AMBT test the coarse aggregate had to be crushed to obtain the required standard sizes [2] and the fine aggregate was used in their natural size. In all cases, a size smaller than $4.75 \mathrm{~mm}$ was used and the particles passing the sieve 0.15 were discarded. The size distribution for each type of aggregate is shown in Table 2.

Table 2: Aggregate size distribution for the AMBT test.

\begin{tabular}{ccc|ccc}
\hline \multirow{2}{*}{ Type of aggregate } & \multicolumn{5}{c}{ Sieve (mm) } \\
\cline { 2 - 6 } & $\mathbf{2 . 3 6}$ & $\mathbf{1 . 1 8}$ & $\mathbf{0 . 6 0}$ & $\mathbf{0 . 3 0}$ & $\mathbf{0 . 1 5}$ \\
\hline Coarse & $10 \%$ & $25 \%$ & $25 \%$ & $25 \%$ & $15 \%$ \\
Coarse Sand & $10 \%$ & $25 \%$ & $25 \%$ & $40 \%$ & - \\
Fine Sand & - & - & - & $85 \%$ & $15 \%$ \\
\hline
\end{tabular}

For the record of the bars length a vertical comparator of $15 \mathrm{~mm}$ of maximum displacement and a $300 \mathrm{~mm}$ reference bar were used. All the bars were from $25 \times 25 \times 285(\mathrm{~mm} \times \mathrm{mm} \times \mathrm{mm})$ with nominal length of $250 \mathrm{~mm}$. Three bars were casted for each mortar. 
VILA, P; PEREYRA, M.N. APPLICATION OF THE KINETIC ANALYSIS IN THE ACCELERATED TEST OF ALKALI-SILICA REACTION IN AGGREGATES FOR CONCRETE. $4^{\circ}$ Simpósio Paranaense de Patologia das Construções (40 SPPC), artigo 4SPPC159, pp. 534 - 546, 2019. DOI: 10.4322/2526-7248.075

\subsection{Methodology}

The initial length $\left(\mathrm{L}_{t 0}\right)$, the length at intermediate test times $\mathrm{L}_{\mathrm{ti}}$ and the length at the end of the immersion period were recorded for each bar during 28 days of immersion in the aggressive solution of $1 \mathrm{~N} \mathrm{NaOH}$ at $80^{\circ} \mathrm{C}$ (AMBT methodology test in the IRAM 1674 standard) [3].

The expansion of each bar to certain immersion age $E_{t}$ was calculated as the difference between length at that age $L_{t i}$ and the initial length $L_{t 0}$. This was referred to the nominal length of the bar $L_{n}(250 \mathrm{~mm})$ in percentage according to Eq.2.

$\operatorname{Et}(\%)=100 *\left(\mathrm{~L}_{\mathrm{ti}}-\mathrm{L}_{\mathrm{t} 0}\right) / \mathrm{L}_{\mathrm{n}}$

The result of an aggregate sample expansion is calculated as the average expansion of three bars tested. The coefficient of variation per sample was calculated to verify the accuracy of measurements of the different bars, according to the limits indicated by the ASTM C1260 [2].

To analyze the reaction evolution depending on the immersion time $t$, the growth curve of the expansion relative to the expansion E14 (\%) and the kinetic analysis were determined applying the mathematical model, according the RILEM recommendations [1]. Doing a variable change by applying the double natural logarithm on both sides of the Eq.1, a lineal behavior model in the variables $y$ and $x$ was obtained according to Eq.4 and Eq.5.

$\mathrm{y}=\mathrm{M} * \mathrm{x}+\operatorname{lnk}$

Where:

$\mathrm{y}=\ln \left(\ln \left(\frac{1}{1+\mathrm{E}_{\mathrm{t} 1}-\mathrm{E}_{\mathrm{t}}}\right)\right)$

$x=\ln \left(t-t_{1}\right)$

A linear adjustment of the model to the experimental data was carried out and the kinetic parameter $\mathrm{M}$ and Lnk of the Eq.3 were obtained. For the coefficients calculation the expansion up to 14 days was adopted (the coefficients were identified as M14 and Lnk14).

The induction time $t_{1}$ was adopted as the first intermediate recording ( 3 days) taken during the 28 days of immersion. 
VILA, P; PEREYRA, M.N. APPLICATION OF THE KINETIC ANALYSIS IN THE ACCELERATED TEST OF ALKALI-SILICA REACTION IN AGGREGATES FOR CONCRETE. $4^{\circ}$ Simpósio Paranaense de Patologia das Construções (40 SPPC), artigo 4SPPC159, pp. 534 - 546, 2019. DOI: 10.4322/2526-7248.075

The kinetic model error was calculated at 21 days and 28 days. This was estimated as the absolute relative difference (in percentage) between the calculated expansion (Eti cal) and the experimental expansion at 21 and 28 days according to the Eq.6.

$\operatorname{error} E(t i)=\frac{a b s(\text { Eti cal-Eti exp })}{\text { Eti exp }} \times 100$

Where errorE(ti) is the estimated error, (Eti cal) the percentage referred to experimental expansion (Eti exp). $t i$ is the time at 21 days and 28 days.

\section{Results}

\subsection{Expansion evolution}

The average of the expansion of three bars immersed in the aggressive solution was calculated (according to Eq.2). Figure 3.1 shows the results for 28 days of immersion. For a better visualization of the results, the tests graphics were identified with colors according to the standard reactivity criterion (IRAM 1674) for the expansion at 14 days of immersion E14 (E14>0.2 \%: red; 0.1\%<E14<0.2\%: orange, E14<0.1\%: green).

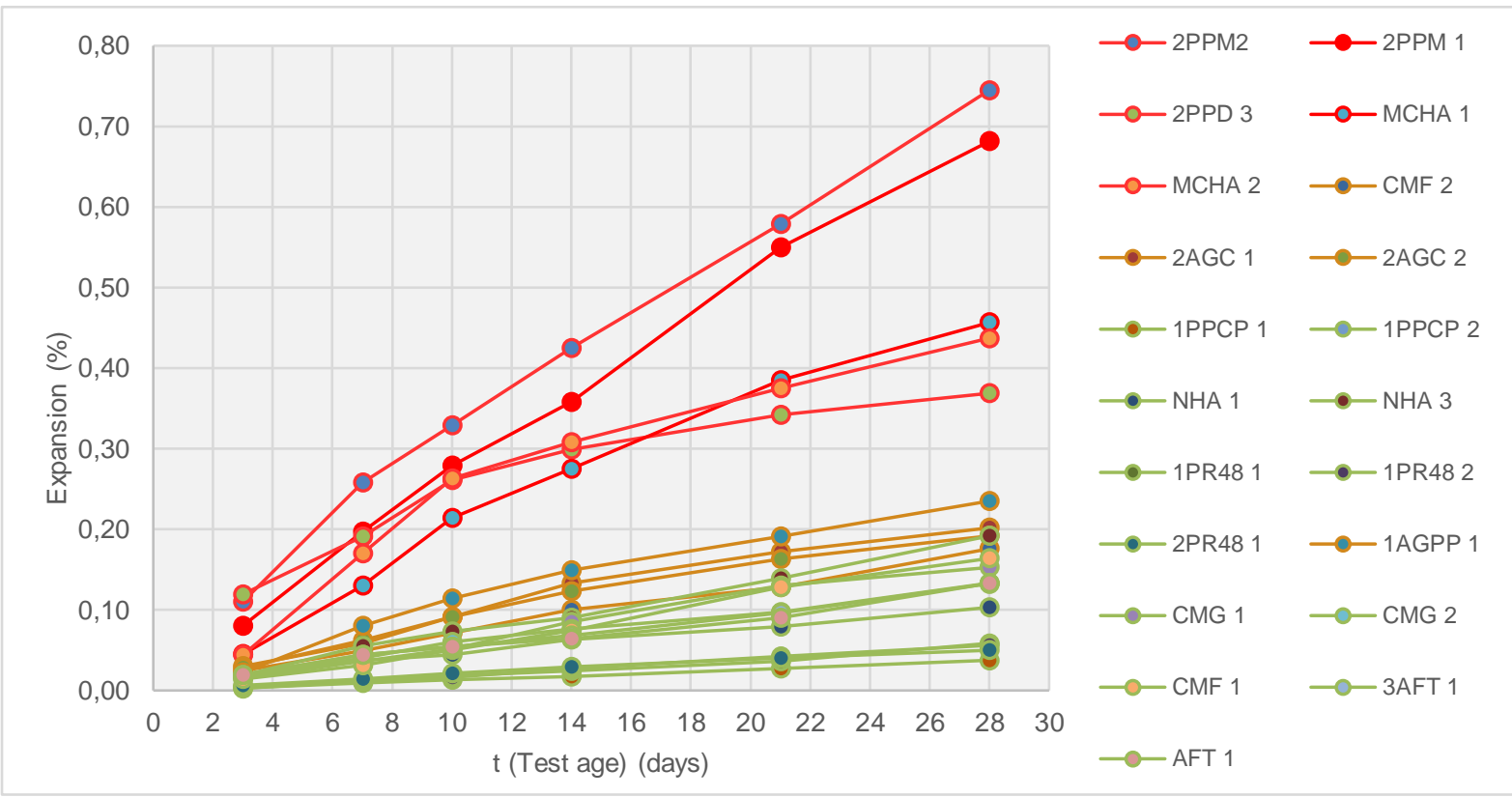

Figure 3.1: Expansion graphs up to 28 days of immersion in $\mathrm{NaOH}$. 
VILA, P; PEREYRA, M.N. APPLICATION OF THE KINETIC ANALYSIS IN THE ACCELERATED TEST OF ALKALI-SILICA REACTION IN AGGREGATES FOR CONCRETE. $4^{\circ}$ Simpósio Paranaense de Patologia das Construções (40 SPPC), artigo 4SPPC159, pp. 534 - 546, 2019. DOI: $10.4322 / 2526-7248.075$

The evolution of the expansion E14 is represented on graphics of Figure 3.2.

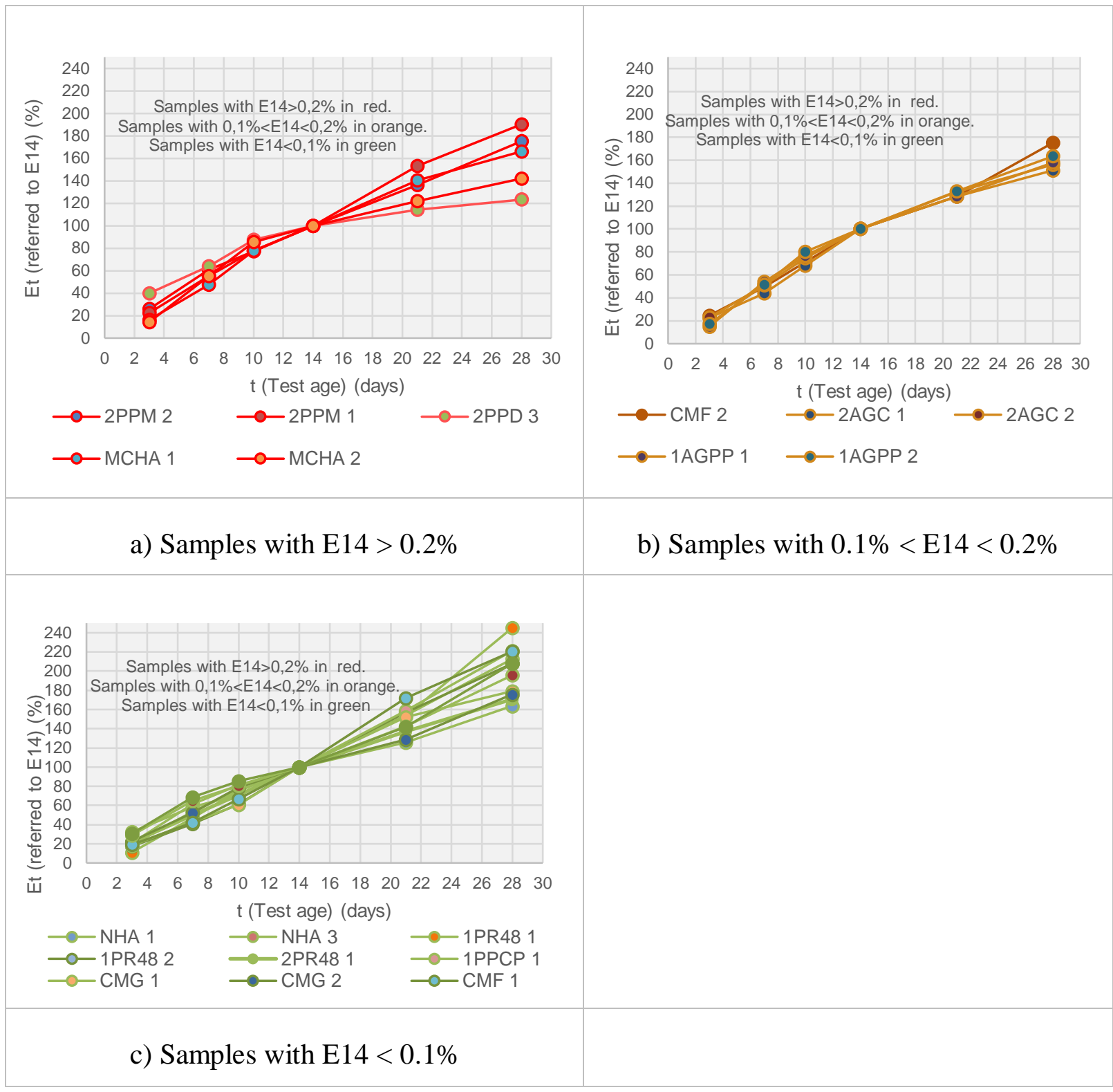

Figure 3.2: Expansion evolution graphics relative to E14.

The samples with $\mathrm{E} 14>0.2 \%$ presented an expansion between $20 \%$ and $90 \%$ greater at 28 days than at 14 days. A different evolution of the expansion was observed among them: 2PPD3 presented a faster growth than the rest of the samples (after 14 days and up to 28 days there was an increase of only 20\%), the 2PPM1, 2PPM2 and MCHA1 presented the slower growth and less asymptotic behavior (after 14 days and up to 28 days there was an increase between $66 \%$ y $90 \%$ ).

The samples with E14 between $0.1 \%$ and $0.2 \%$ presented similar behavior of the expansion. After 14 days there was a growth of approximately $60 \%$ for all the samples. The samples with $\mathrm{E} 14<0.1 \%$ for 28 days presented an expansion from $55 \%$ and up to $154 \%$ higher than the expansion at 14 days. 
VILA, P; PEREYRA, M.N. APPLICATION OF THE KINETIC ANALYSIS IN THE ACCELERATED TEST OF ALKALI-SILICA REACTION IN AGGREGATES FOR CONCRETE. $4^{\circ}$ Simpósio Paranaense de Patologia das Construções (40 SPPC), artigo 4SPPC159, pp. 534 - 546, 2019. DOI: $10.4322 / 2526-7248.075$

\subsection{Application of the kinetic model}

The kinetic model coefficients (Lnk and M according Eq.3) determined by the change of variables $y$ and $x$ (Eq.4 and Eq.5) were adjusted by the least square technique to the experimental data (graph in Figure 3.3). The calculation of the coefficients identified as Lnk14d and M14d - was made with the expansion up to 14 days.

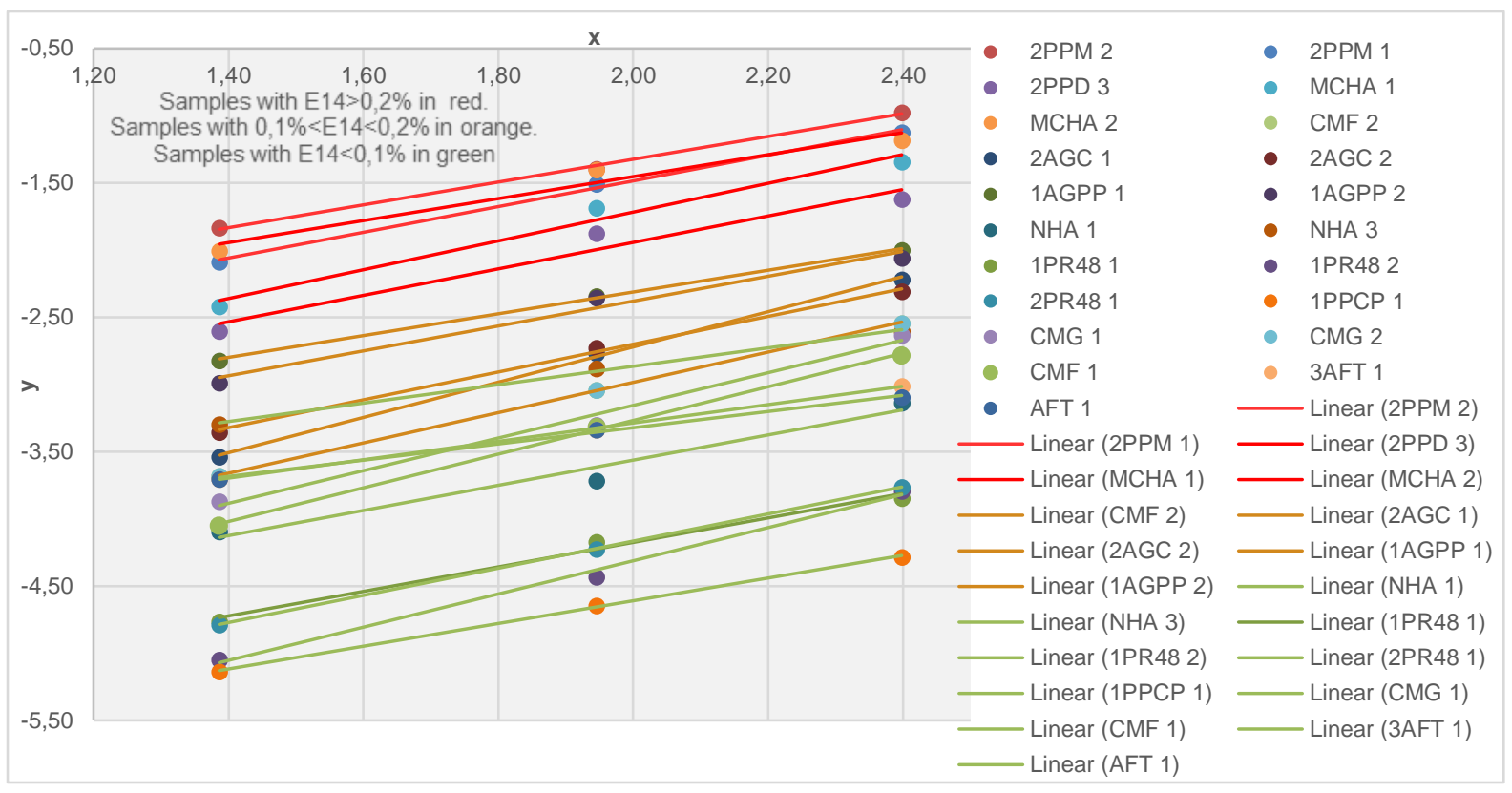

Figure 3.3. Model kinetic graph for the samples with expansion up to 14 days.

The variable " $y$ " values are negative. It is observed that " $y$ " increased with the test age. For each sample only three results were used for the adjustment (at 7 days, 10 days and 14 days) (in all the cases the model presented an $R^{2}>0,92$ ). The value at 3 days was the induction time (t1).

For the test age $t$ a greater expansion result corresponds to a greater difference Et1Et and consequently a greater value of the variable y. This is the reason why the lineal regression model "moves towards the axis of the abscissa" when the expansion is greater.

Figure 3.4 shows the scattergram and summarizes the statistical parameters of the coefficient M14 and Lnk14. The coefficient M presented values closed to 1 . Samples with $\mathrm{E} 14>0.2 \%$ and $0.1 \%<\mathrm{E} 14<0.2 \%$ presented $\mathrm{M}$ values with a smaller scatter than samples with $\mathrm{E} 14<0.1 \%$ (range of $0.245,0.200$ and 0.650 ). This shows the greatest variation in the growth of the expansion presented up to 28 days of immersion in the samples with E14<0.1\% (Figure 3.2).

Lnk presented values between -6.783 and -3.022 (Figure 3.4). The samples with E14 $>0.2 \%$ presented the highest values, the samples with $0.1 \%<E 14<0.2 \%$ and some of the samples with $\mathrm{E} 14<0.1 \%$ presented intermediate values. The samples with $E 14<0.1 \%$ showed the highest scatter (a range of 2.547 against 0.891 and 1.305 for the other two cases). 


\begin{tabular}{|c|c|c|c|c|}
\hline & & & \\
\hline
\end{tabular}

Figure 3.4: Scattergram and statistical parameters of the coefficients M14 and Lnk14.

Analyzing together the evolution of the reaction and the parameter arising from the application of the kinetic model it could be observed that the M coefficient is associated with the growth of the reaction. The aggregates with the fastest reaction growth presented a lower value of $\mathrm{M}$.

The Lnk coefficient (interception of the line with the ordinate axis) not only depends on the relative growth of the expansion at different test times, but also on the magnitude of the expansion.

Previous researchers [11] [14] concluded that higher values of Lnk and lower values of $\mathrm{M}$ indicated high reactivity aggregates. Higher values of Lnk are associated with high expansion values and therefore considered expansive. However, for lower values of Lnk the aggregate reactivity degree will depend on the parameter M. Lower values of Ink together with lower values of $\mathrm{M}$ (more asymptotic behavior) indicate a better aggregate behavior.

Both kinetic parameters ( $\mathrm{M}$ vs Lnk) were graphed allowing a better visualization of their behavior (Figure 3.5). On the same graph coefficients from the literature are presented identifying reactivity zones according to field experience [11] [14]. As a general trend it could be observed that the coefficients that arise from the experimental data showed similar values to some of those reported in the literature which allowed to reinforce (or extend) the field experience analysis reported. 
VILA, P; PEREYRA, M.N. APPLICATION OF THE KINETIC ANALYSIS IN THE ACCELERATED TEST OF ALKALI-SILICA REACTION IN AGGREGATES FOR CONCRETE. $4^{\circ}$ Simpósio Paranaense de Patologia das Construções (40 SPPC), artigo 4SPPC159, pp. $534-546$, 2019. DOI: $10.4322 / 2526-7248.075$

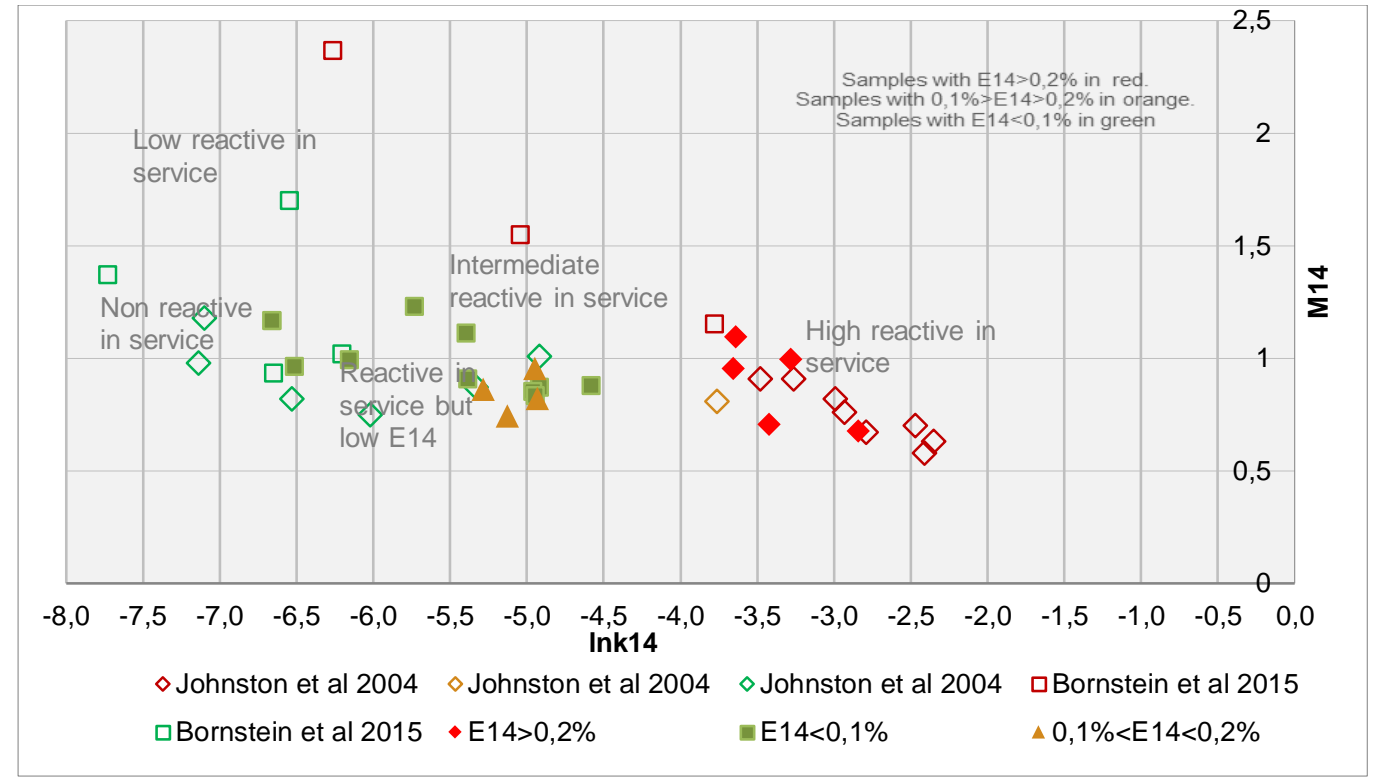

Figure 3.5: Graph M14 vs Lnk14. Experimental and literature data.

\subsection{Error of the expansion estimation at 21 and 28 days}

The expansions at 21 and 28 days were calculated adopting the kinetic model. Then the error in the estimation (errorEti) at 21 and 28 days was calculated according to Eq.6. In Figure 3.4 it can be observed the scattergram and the summary of the statistical parameters of the error.

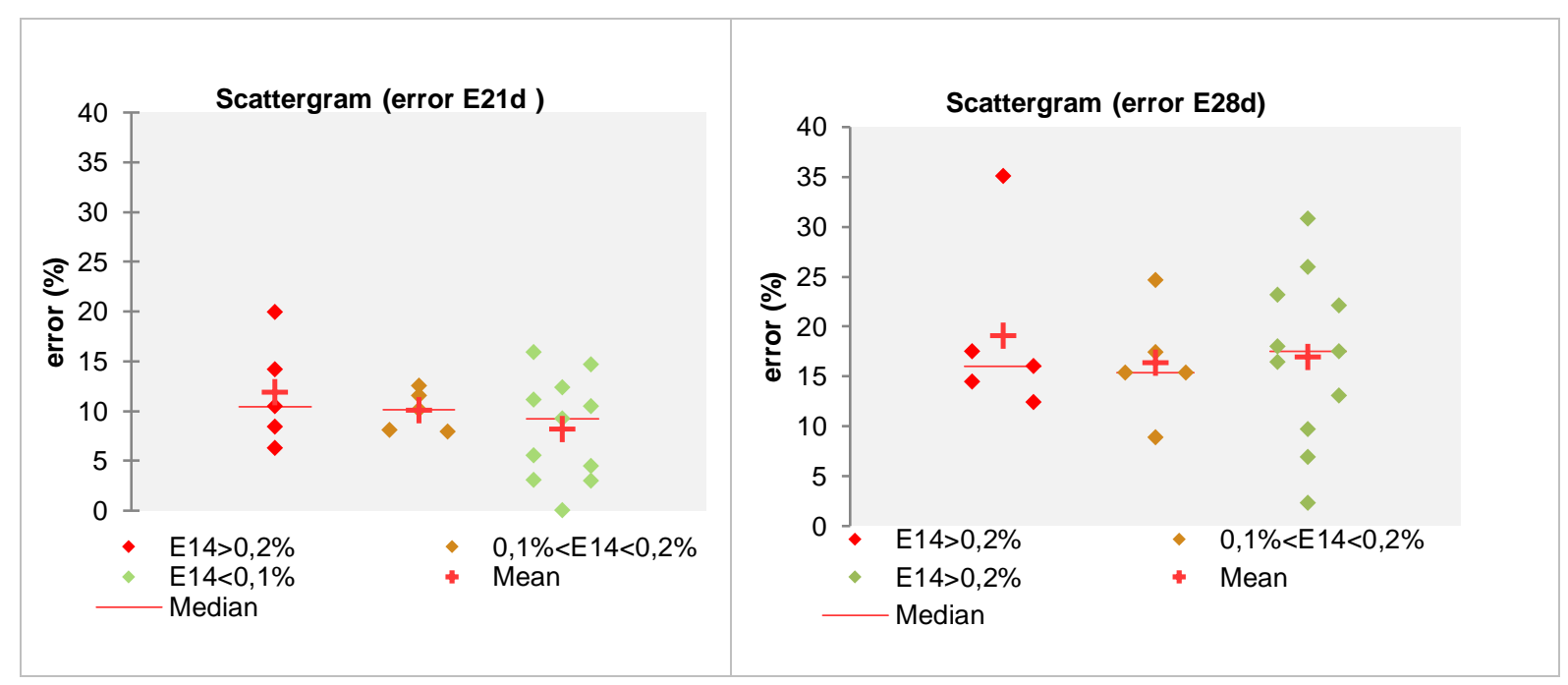


VILA, P; PEREYRA, M.N. APPLICATION OF THE KINETIC ANALYSIS IN THE ACCELERATED TEST OF ALKALI-SILICA REACTION IN AGGREGATES FOR CONCRETE. $4^{\circ}$ Simpósio Paranaense de Patologia das Construções (40 SPPC), artigo 4SPPC159, pp. 534 - 546, 2019. DOI: $10.4322 / 2526-7248.075$

\begin{tabular}{|c|c|c|c|}
\hline \multicolumn{4}{|c|}{ Summary of error E21d } \\
\hline error E21d & $\begin{array}{c}\text { E14>0,2 } \\
\%\end{array}$ & $\begin{array}{c}0,1 \%>\text { E14>0, } \\
2 \%\end{array}$ & E14<0,1\% \\
\hline $\begin{array}{l}\text { Sample } \\
\text { size }\end{array}$ & 5 & 5 & 11 \\
\hline Minimum & 6,295 & 7,936 & 0,036 \\
\hline Maximum & 19,944 & 12,554 & 15,874 \\
\hline Range & 13,649 & 4,619 & 15,838 \\
\hline Median & 10,436 & 10,101 & 9,228 \\
\hline Mean & 11,843 & 10,047 & 8,156 \\
\hline 3rd Quartile & 14,163 & 11,521 & 11,710 \\
\hline
\end{tabular}

\begin{tabular}{cccc} 
Summary of error E28d & & \\
\hline error E28d & $\mathbf{E 1 4 > 0 , 2 \%}$ & $\begin{array}{c}\mathbf{0 , 1} \mathbf{0}>\mathbf{E 1 4}>\mathbf{0}, \\
\mathbf{2 \%}\end{array}$ & $\mathbf{E 1 4 < \mathbf { 0 , 1 } \%}$ \\
\hline Sample size & 5 & 5 & 11 \\
Minimum & 12,391 & 8,878 & 2,264 \\
Maximum & 35,051 & 24,649 & 30,764 \\
Range & 22,660 & 15,771 & 28,500 \\
Median & 16,045 & 15,377 & 17,514 \\
Mean & 19,080 & 16,334 & 16,887 \\
3rd Quartile & 17,466 & 17,389 & 22,625 \\
\hline
\end{tabular}

Figure 3.4. Scattergram and statistical parameters of the error E21d and error E28d.

The average estimation error at 21 days was close to $10 \%$. The samples with $0.1 \%<E 14<0.2 \%$ presented the lowest scatter (a range of 4.619 against 13.649 for the samples with $\mathrm{E}>0.2 \%$ and 15.838 for the samples with $\mathrm{E} 14<0.1 \%)$.

The average estimation error at 28 days was close to $17 \%$. The samples with $0.1 \%<E 14<0.2 \%$ presented the lowest scatter (a range of 15.771 against 22.660 for the samples with $\mathrm{E}>0.2 \%$ and 28.500 for the samples with $\mathrm{E} 14<0.1 \%$ ).

It should be considered that the age of 21 and 28 days are out of the age range used to determine the kinetic model (between 3 and 14 days).

\section{Conclusions}

The evolution of the expansion up to 14 days of immersion in the accelerated mortar bar test (AMBT) for the study of RAS has been correlated with the mathematical model recommended by the RILEM Technical Committee 219-ACS. The kinetic model determined by least squares adjustment to the expansion experimental data was calculated using ages of 3 to 14 days of bars immersion in the $\mathrm{NaOH}$ aggressive solution.

The kinetic parameters Lnk and $M$ were good indicators of the magnitude and evolution of the expansion with the test age. Therefore, the interpretation of the test AMBT with the use of both parameters was improved. However, to be able to define a limit value for the coefficients, it is necessary to establish a correlation with the concrete prisms of long duration (1 year or more) or aggregate behavior field experience.

The model allowed the expansion estimation at 21 and 28 days. Therefore, when the kinetic model is applied it will not be necessary to continue the AMBT test beyond the 14 days. The error in the estimation should be considered: close to $10 \%$ at 21 days and $17 \%$ at 28 days (in the samples tested). 
VILA, P; PEREYRA, M.N. APPLICATION OF THE KINETIC ANALYSIS IN THE ACCELERATED TEST OF ALKALI-SILICA REACTION IN AGGREGATES FOR CONCRETE. $4^{\circ}$ Simpósio Paranaense de Patologia das Construções (40 SPPC), artigo 4SPPC159, pp. 534 - 546, 2019. DOI: $10.4322 / 2526-7248.075$

\section{Acknowledgements}

Thanks to the Structures and Transport Institute (IET) of the Engineering University (UdelaR) for the equipment and laboratory necessary to carry out the test, as well as the CSIC (Cience Investigation Comitee) and Concrexur S.A. for the project financing and the private companies that provided the materials for the study.

\section{References}

[1] Nixon, P y Sims, I. (2016), RILEM Recommendations for the Prevention of Damage by Alkali-Aggregate Reactions in New Concrete Structures, State-of-theArt. Report of the RILEM Technical Committee 219-ACS.

[2] ASTM C1260 (2014), Standard Test Method for Potential Alkali Reactivity of Aggregates (Mortar-Bar Method), ASTM International, West Conshohocken, PA, 2014, www.astm.org.

[3] IRAM 1674 (1997), Agregados. Determinación de la Reactividad Alcalina Potencial Método Acelerado de la Barra de Mortero, Instituto Argentino de Normalización y Certificación, Argentina.

[4] NBR 15577-4 (2009), Agregados - Reatividade álcali-agregado. Parte 4: Determição de expansão em barras de argamassa pelo método acelerado. Associação Brasilera de Normas Técnicas, Brasil.

[5] AENOR UNE 146508 EX (1999), Ensayos de áridos. Determinación de la reactividad potencial álcali-sílice y álcali-silicato de los áridos. Método acelerado en probetas de mortero. Asociación Española de Normalización y Certificación, España.

[6] IRAM 1700 (2013), Agregados. Método para la determinación del cambio de largo en prismas de hormigón, debido a la reacción álcali-agregado. Instituto Argentino de Normalización y Certificación, Argentina.

[7] ASTM C1293-08b (2015), Standard Test Method for Determination of Length Change of Concrete Due to Alkali-Silica Reaction, ASTM International, West Conshohocken, PA, 2015, www.astm.org.

[8] Falcone D., Milanesi, C., Método acelerado del prisma de hormigón. Evaluación de la RAS con agregados de diversas regiones de la Argentina, en el $V$ Congreso Internacional y 19ํReunión Técnica de la AATH, Bahía Blanca, Argentina, 2012.

[9] Johnston, D. y Fournier, B., A kinetic-based method for interpreting accelerated mortar bar test (ASTM C1260) data, en Alkali-Aggregate Reaction, Proceedings of the 11th International Conference, Québec, Canada, 2000, 355-364.

[10] Stokes, D., Concerning the Use of Expansion Data from AST Testing, en MarcAndre Berube Symposium on Alkali-Aggregate Reactivity in Concrete, $\mathrm{ACl}$ International Conference on Recent Advances in Concrete Technology, Québec, Canada, 2006. 
VILA, P; PEREYRA, M.N. APPLICATION OF THE KINETIC ANALYSIS IN THE ACCELERATED TEST OF ALKALI-SILICA REACTION IN AGGREGATES FOR CONCRETE. $4^{\circ}$ Simpósio Paranaense de Patologia das Construções (40 SPPC), artigo 4SPPC159, pp. 534 - 546, 2019. DOI: 10.4322/2526-7248.075

[11] Johnston, D., Stokes, D., Fournier, B., Surfahl, R. Oy otros (2000), Kinetic characteristics of ASTM C1260 testing and ASR-induced concrete damge, en 12th International Conference on Alkali-Aggregate Reaction in Concrete, Beijung, China, 2004.

[12] UNIT 1050 (2005), Proyecto y ejecución de estructuras de hormigón en masa o armado. Instituto Uruguayo De Normas Técnicas, (Montevideo, Uruguay), p. 288.

[13] UNIT 20 (2017), Cemento pórtland para uso general. Definiciones y requisitos. Instituto Uruguayo De Normas Técnicas, (Montevideo, Uruguay), p. 13.

[14] Bronstein, B., Hocking, D., Bacolod, J. Sirivivatnanon., V. (2015), The use of reaction kinetics in classifying alkali silica reactivity potential of aggregates, in Proceddings of the concrete 2015 conference: 27 th biennial national conference of the concrete institute of Australia in conjunction with the 69th RILEM week conference, 2015, pp. 704-711. ISBN: 978-1-943847-70-9. 